\title{
Scaffold proteins ITSN1 and ITSN2 interact with nuclear RNA-binding proteins
}

\author{
S. V. Pankivskyi, N. V. Senchenko, P. B. Busko, A. V. Rynditch \\ Institute of Molecular Biology and Genetics, NAS of Ukraine \\ 150, Akademika Zabolotnoho Str., Kyiv, Ukraine, 03143 \\ s.v.pankivskyi@imbg.org.ua
}

\begin{abstract}
Aim. To identify novel ITSN1 and ITSN2 partners among RNA-binding proteins (RBPs) involved in the regulation of mRNA processing. Methods. The interactions were revealed using GST pull-down and immunoprecipitation assays whereas bioinformatics analysis was used to identify other RBPs that could interact with proteins ITSN1 and ITSN2. Results. It was shown that ITSN1 and ITSN2 SH3 domains interacted with nuclear RBPs SAM68, WBP11, and LARP6 in vitro. Next, it was found that ITSN1 and ITSN2 co-precipitated with SAM68 and LARP6 from 293 cells lysates. Finally, the bioinformatics analysis identified more than 500 nuclear RBPs that contain several SH3 domain-interacting proline motifs and could bind ITSN1/2. Conclusions. ITSN1 and ITSN2 SH3 domains bind nuclear RBPs SAM68, LARP6, and WBP11 in vitro, form complexes with SAM68 and LARP6 in 293 cells, and potentially could interact with other nuclear RBPs containing SH3 domain-interacting motifs.
\end{abstract}

Ke y w o r d s: ITSN1, ITSN2, RNA-binding proteins.

\section{Introduction}

Scaffold proteins represent a group of biomolecules that are involved in the modulation of various cellular processes. These proteins are composed of multiple protein-interacting domains and serve as platforms for the formation of functional protein complexes [1]. Intersectins (ITSN1 and ITSN2) are evolutionarily conserved scaffold proteins encoded by two paralogous genes. Short isoforms of ITSN1 (ITSN1s) and ITSN2 (ITSN2s) possess identi- cal domain structure and consist of two Eps15 homology domains (EH) that bind Asp-ProPhe (NPF) motifs, a coiled-coil region providing homo- and heterodimerization and five SH3 domains that interact with proline-rich motifs [2]. Long isoforms of ITSN1 (ITSN11) and ITSN2 (ITSN21) contain additional C-terminal DH-PH-C2 domains involved in the specific activation of GTPase Cdc42 [3]. ITSN1s, ITSN2s and ITSN21 are expressed ubiquitously whereas ITSN11 is expressed only in neurons [4]. ITSN1/2 are known to interact

(C) 2019 S. V. Pankivskyi et al.; Published by the Institute of Molecular Biology and Genetics, NAS of Ukraine on behalf of Biopolymers and Cell. This is an Open Access article distributed under the terms of the Creative Commons Attribution License (http://creativecommons.org/licenses/by/4.0/), which permits unrestricted reuse, distribution, and reproduction in any medium, provided the original work is properly cited 
with proteins involved in clathrin-mediated endocytosis and actin cytoskeleton remodeling, as well as with components of some cell signaling cascades including MAPK-, PI3KC2 $\beta$-, and JNK-mediated pathways [4].

ITSN1 and ITSN2 were found to be involved in oncogenesis. First, ITSN1 overexpression induces the oncogenic transformation of rodent fibroblasts [5] and stimulates the invadopodia formation [6]. Second, overexpression of ITSN1 is associated with the development of neuroblastoma $[7,8]$ and glioblastoma $[9,10,11]$. However, the ectopic expression of ITSN1 suppresses the proliferation, growth and migration of lung cancer cells [12]. Similarly, high levels of ITSN2 in breast cancer patients are associated with prolonged disease-free survival [13].

Previously, the analysis of HeLa nuclei phosphoproteome identified ITSN1 peptides in the nuclei of HeLa cells [14]. More recently, ITSN1 has been found to undergo nucleus-cytoplasmic shuttling via CRM1- and importin $\alpha$-dependent pathways and has been shown to co-localize with lamin A/C [15]. The data supports our observations revealing nuclear localization of ITSN1 (unpublished data). However, the role of nuclear localization of ITSN1 is unknown.

Several high-throughput studies based on the results of two-hybrid screenings [16, 17] and phage display [18] identified ITSN1/2 proteins as putative partners of nuclear RNAand DNA-binding proteins whereas the role of the protein complexes in a cell is unknown. We suggested that ITSN1/2 SH3 domains play an essential role in the interaction between ITSN1/2 and RNA-binding-proteins (RBPs) as multiple RBPs possess proline-rich motifs that directly interact with $\mathrm{SH} 3$ domains whereas ITSN1/2-RBPs complexes might be involved in novel nucleus-cytoplasm crosstalk pathways.

Therefore, the current work aimed to confirm the interactions between ITSN1/2 proteins and RBPs identified in different high-throughput studies using GST pull-down and immunoprecipitation assays. Moreover, using a bioinformatics approach, we analyzed RBPs present in human proteome to find additional proline-rich motifs as potential ITSN1/2-binding sites.

\section{Materials and Methods}

Expression constructs. The plasmids encoding human GST-fused SH3 domains-containing fragment of ITSN1 and ITSN2 were described previously $[19,20]$. SAM68-GFP was a kind gift of Dr. D. J. Elliott [21], WBP11-GFP was received from Dr. M.Bollen [22], and LARP6GFP was obtained from Dr. L. M. Schwartz [23].

Antibodies. Rabbit polyclonal antibodies against ITSN1 and ITSN2 were described previously $[19,20]$. Polyclonal anti-GFP antibodies were a kind gift of Dr. V. V. Filonenko. Secondary HRP-labeled anti-rabbit antibodies were purchased from Promega.

Cell culture and transfection. 293 cells were maintained in Dulbecco's modified Eagle's medium (DMEM) supplemented with $10 \%$ fetal bovine serum (Sigma), $50 \mathrm{mg} / \mathrm{ml}$ penicillin and $100 \mathrm{mg} / \mathrm{ml}$ streptomycin. The cells were transiently transfected using JetPEI transfection reagent (Polyplus Transfection) according to recommended protocol and were processed $24 \mathrm{~h}$ following transfection.

Pull-down assay. The recombinant GSTfused proteins were produced in Escherichia 
coli Top10 cells and purified using glutathioneSepharose 4B (GE Healthcare) according to the manufacturer's protocol. Lysates of transiently transfected 293 cells were prepared in extraction buffer containing $20 \mathrm{mM}$ Tris- $\mathrm{HCl}$ $\mathrm{pH} 7.4,150 \mathrm{mM} \mathrm{NaCl}, 0.5 \%$ Triton X-100, 1 mM EDTA and $1 \mathrm{mM}$ phenylmethylsulfonylfluoride (PMSF) and centrifuged for $10 \mathrm{~min}$ at $12.000 \mathrm{rpm}$ at $4^{\circ} \mathrm{C}$. For pull-down experiments, 5-10 $\mu \mathrm{g}$ of GST or GST-fused proteins were bound to $30 \mu \mathrm{l}$ of $50 \%$ glutathioneSepharose 4B beads and incubated with the 293 cell lysates for $1 \mathrm{~h}$ at $4^{\circ} \mathrm{C}$. After extensive washing, the beads were boiled in Laemmli sample buffer.

Immunoprecipitation assay. The immunoprecipitation was performed as described previously [20]. In brief, 293 cells were lysed in IP buffer (150 mM NaCl, $20 \mathrm{mM}$ Tris, $\mathrm{pH} 7.5$, $10 \%$ glycerol, $0.5 \%$ NP40, protease inhibitors cocktail (Roche) and centrifuged for $15 \mathrm{~min}$ at $12,000 \mathrm{rpm}$. The supernatant ( $2 \mathrm{mg}$ of proteins) was incubated with $2 \mu \mathrm{g}$ of anti-ITSN1 or anti-ITSN2 antibodies and $20 \mu 1$ of Protein G-conjugated agarose beads (Santa Cruz Biotechnology) for $4 \mathrm{~h}$ at $4^{\circ} \mathrm{C}$. Then, beads were washed three times with IP buffer and boiled in Laemmli sample buffer.

Western blot. Protein samples in Laemmli buffer were resolved by SDS-PAGE and transferred to nitrocellulose membranes (Bio-Rad). The membranes were blocked with $5 \%$ non-fat milk in TBS-T (1xTBS, $0.1 \%$ Tween 20) for $1 \mathrm{~h}$, incubated with anti-GFP, anti-ITSN1 or anti-ITSN2 antibodies for $1 \mathrm{~h}$ and washed. Next, membranes were incubated with HRPconjugated secondary anti-rabbit antibodies for $1 \mathrm{~h}$. Immunoreactive bands were detected using ECL reagents. Chemiluminescence was captured with Molecular Imager ChemiDoc ${ }^{\mathrm{TM}}$ XRS+ (Bio-Rad).

Bioinformatics analysis. A list of human RNA-binding proteins was composed using RBPs Databases ATtRACT [24] (last accessed December 21, 2018) and RBPDB [25] (last accessed December 21, 2018) and QuickGO annotation service [26] (last accessed January $28,2019)$ where proteins annotated with GO terms "RNA binding" (GO:0003723) and "experimental evidence used in manual assertion" (ECO:0000269) were obtained. A list of proteins that localize in a cell nucleus was also obtained from QuickGO service using GO term "Nucleus" (GO:0005634). Amino acid sequences of the selected RBPs were acquired from the UniProt database (https://www.uniprot.org/, last accessed December 21, 2019). Proline-rich motifs (PxxP, RxxPxxP, PxxPxR) that potentially interact with $\mathrm{SH} 3$ domains were searched in the amino acid sequences of RBPs automatically using Python scripts.

\section{Results and Discussion}

The putative interaction between ITSN $1 / 2$ and several RNA-binding proteins was studied in vitro. For the purpose, a GST pull-down assay was performed to analyze the binding of ITSN1/2 SH3 domains to the putative partners. The selected RNA-binding proteins included SAM68 (Src-Associated substrate in Mitosis of $68 \mathrm{kDa}$ ), WBP11 (WW Domain Binding Protein 11), and LARP6 (La Ribonucleoprotein Domain Family Member 6). All these proteins contain several PxxP motifs that can potentially interact with ITSN1/2 SH3 domains. As a result, recombinant proteins representing $\mathrm{SH} 3$-containing fragments of ITSN1 $\left(\mathrm{ITSN}_{\mathrm{SH}_{3}}\right)$ and ITSN2 

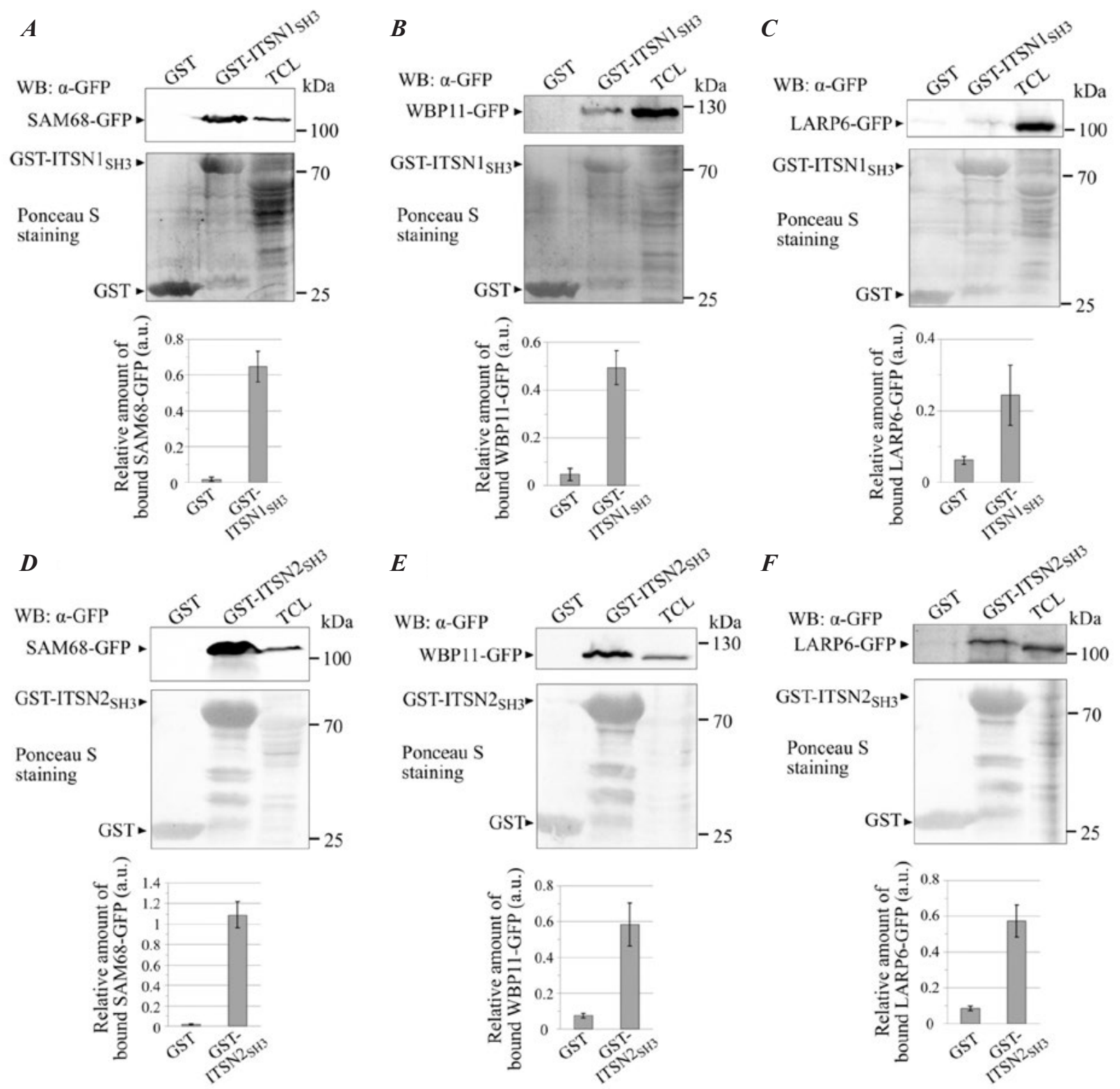

Fig. 1. The SH3 domains of ITSN1 (A, B, C) and ITSN2 (D, E, F) interact with RNA-binding proteins SAM68 (A, D), WBP11 (B, E) and LARP6 (C, F). Following GST pull-down assay and SDS-PAGE, GST-fused SH3 domains of ITSN1 and ITSN2 were visualized using Ponceau staining whereas GFP-fused RBPs were detected using $\alpha$-GFP antibodies. The relative amounts of RBP bound to GST or GST-ITSN1/2 $\mathrm{SH}_{3}$ were calculated using ImageJ software. Histograms represent mean \pm SD values obtained from three separate assays. WB - Western blotting, TCL - total cell lysate, a.u. - arbitrary units. 
(ITSN2 ${ }_{\mathrm{SH} 3}$ ) fused to GST were immobilized on the glutathione sepharose and incubated with the lysates of 293 cells overexpressing one of the target proteins. Recombinant GST alone was used as a negative control. Following gel electrophoresis, GST-fused ITSN $_{\mathrm{SH}_{3}}$ and ITSN2 ${ }_{\mathrm{SH} 3}$ were detected with Ponceau staining whereas precipitated proteins were detected by Western blot. The analysis demonstrated that ITSN1 SH3 domains precipitated all studied RNA-binding proteins (Fig. 1 A, B, C) whereas SAM68 showed the most significant binding. Similar data were obtained for ITSN2 SH3 domains that showed binding to all analyzed RNA-binding and strong interaction with SAM68 (Fig. 1 D, E, F). These data suggest that ITSN1 and ITSN2 interacted with RBPs SAM68, WBP11 and LARP6 in vitro.

Immunoprecipitation assay was used to obtain the formation of complexes between ITSN $1 / 2$ proteins and selected RBPs in 293 cells. For this purpose, antibodies specific to ITSN1 or ITSN2 were immobilized on protein G-containing agarose beads and were incubated with the lysates of 293 cells overexpressing one of the target proteins. ITSN1/ITSN2-containing protein complexes were precipitated and analyzed using Western blot analysis. The data demonstrated that both ITSN1 and ITSN2 precipitated SAM68 and LARP6 suggesting that ITSN1 and ITSN2 form complexes with SAM68 and LARP6 in cells (Fig. 2 A, C, D, F). However, ITSN1 and ITSN2 failed to precipitate WBP11
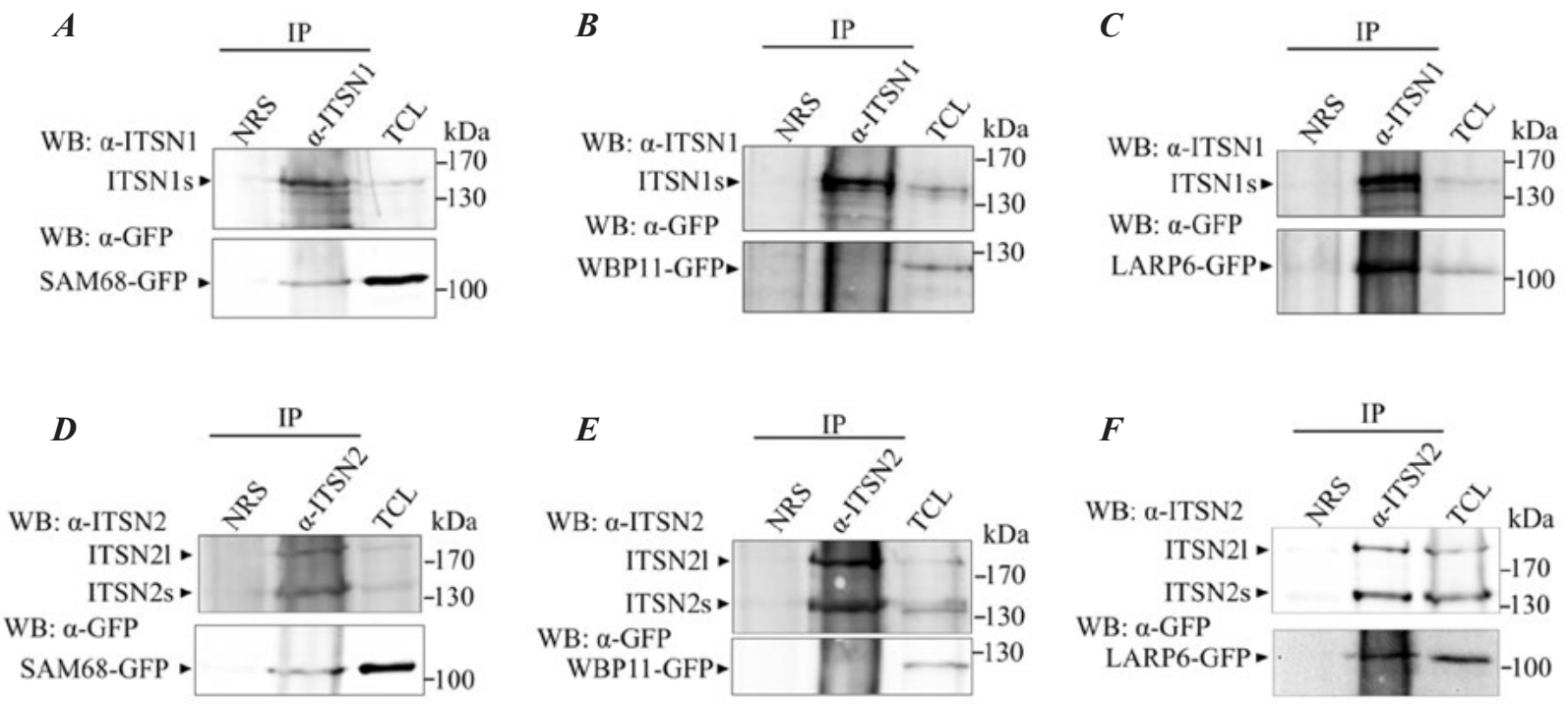

Fig. 2. Endogenous ITSN1 (A, C) and ITSN2 (D, F) precipitate RBPs SAM68 (A, D) and LARP6 (C, F) but did not precipitate WBP11 (B, E) overexpressed in 293 cells. Following immunoprecipitation assay and SDS-PAGE, precipitated proteins ITSN1s (short isoform) or ITSN2s and ITSN21 (short and long isoforms, respectively) were visualized using respective antibodies and ECL detection. Next, the same nitrocellulose membrane was re-incubated with $\alpha$-GFP antibodies to identify co-precipitated RBPs. IP - immunoprecipitation, NRS - normal rabbit serum, WB - Western blot, TCL - total cell lysate. 
(Fig. 2 B, E) that might be caused by the absence of specific external (i.e., mitogenic stimulation) or internal (i.e. posttranslational modification) factors facilitating the interaction.

As multiple RNA-binding proteins contain proline-rich regions, we suggested that ITSN1 and ITSN2 could interact with other RBPs. As a result, we used bioinformatics analysis to screen amino acid sequences of human RBPs for the presence of $\mathrm{SH} 3$ domain-interacting motifs. Using information from RBPs databases and QuickGO service, we identified 1383 RBPs whereas 823 RBPs localized in the nucleus. Next, the presence of proline motifs (PxxP and RxxPxxP/PxxPxR) that are specifically recognized by ITSN1/2 SH3 domains [27] was studied. The analysis demonstrated that most of RBPs contained at least one PxxP motif and almost $28 \%$ of RBPs contained at least one RxxPxxP or PxxPxR motif. The results of the analysis are visualized in the form of Venn diagram (Figure 3A) demonstrating the number of unique and overlapping RBPs according to the studied properties.

However, as one motif might be insufficient for the interaction, or it may be localized inside a protein fold, the number of PxxP and $\mathrm{RxxPxxP} / \mathrm{P} x \mathrm{xP} \mathrm{R}$ motifs in RBPs was analyzed. As we were interested in the identification of putative ITSN1 partners localized in the nucleus, the number of proline motifs in nuclear RBPs is shown (Figure 3B). According to the frequency distribution, nuclear RBPs were characterized by various numbers of proline motifs. Putative ITSN1/2 partners that were identified in the current study (SAM68, WBP11, and LARP6) significantly differed in the number of proline motifs. Similar fre-
$\boldsymbol{A}$

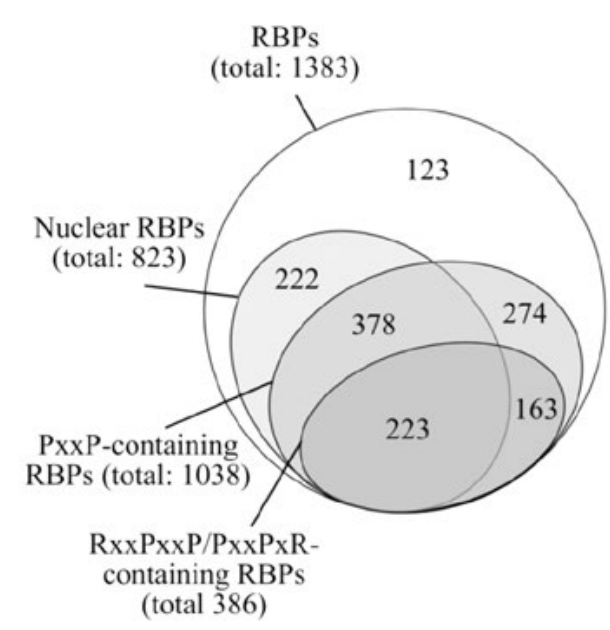

$\boldsymbol{B}$

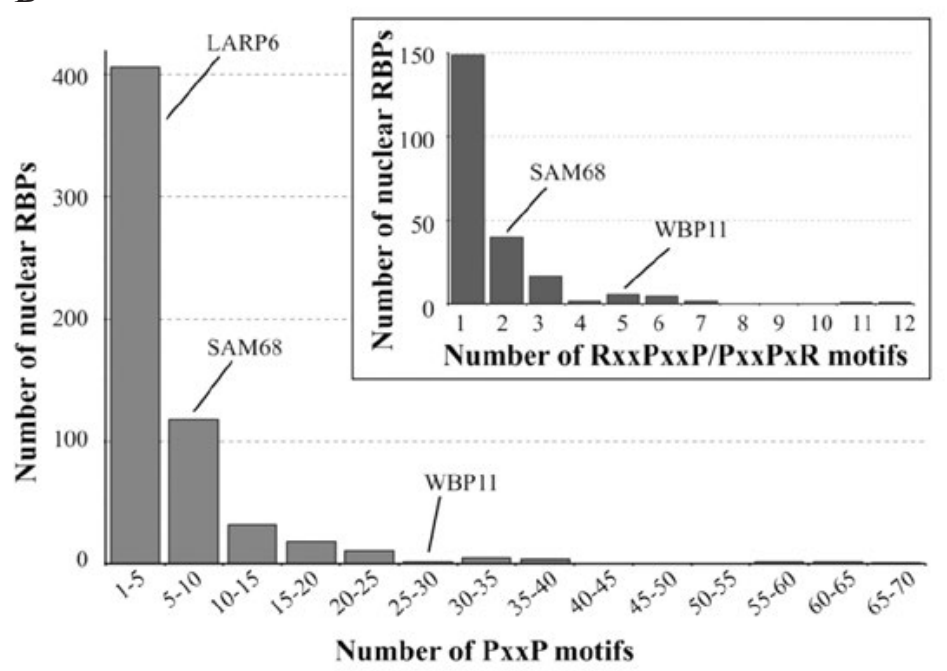

Fig. 3. Multiple RNA binding proteins contain SH3 domain-interacting proline motifs. $A$ - Venn diagram demonstrating a number of all RBPs, nuclear RBPs, and RBPs containing at least one indicated proline motif found in human proteome. $B$ - A histogram showing the frequency of occurrence of certain number of proline motifs identified in nuclear RBPs. 
quency distribution was obtained for cytoplasmic RBPs (data not shown). As a result, it might be suggested that other nuclear and cytoplasmic RBPs containing functional proline motifs could form complexes with ITSN1 and ITSN2 similar to Sam68 and LARP6. However, the experimental evidences are required to confirm the putative interactions.

The present data revealed the interaction between ITSN1/2 proteins and RNA-binding proteins SAM68 and LARP6. Sam68 is involved in the regulation of mRNA processing including its transcription and splicing [28]. In particular, SAM68 modulates the transcriptional activity of acetyl-transferase CBP [29], regulates the expression of cyclins $D I$ and $E$ [30], controls the activation of c-myc targeted genes [31], and is involved in the regulation of androgen receptor-mediated transcription [32]. As a regulator of alternative splicing, SAM68 induces the production of prooncogenic isoforms of $C D 44, C C N D 1, A S F / S F 2$, and BIRC5 [28]. Additionally, the interaction between SAM68 and some SH3 domain-containing proteins (i.e., kinases and methyltransferases) affects its RNA- and protein-binding properties [28]. Moreover, the SAM68 overexpression is observed in different cancer types (breast, glioblastoma, prostate) [28]. LARP6 was found to stimulate the expression of metalloprotease MMP-9. The overexpression of LARP6 is also observed in breast cancer tumors and cell lines [23, 29]. Additionally, LARP6 stimulates angiogenesis and tumor growth [23]. On the other hand, accumulation of ITSN1 in the nucleus leads to the alteration of the expression of immediate response genes (MYC, EGR1, and FOS) whereas the ITSN1 knockdown causes the increased production of proapoptotic isoform of
$A S F / S F 2$ (unpublished data). As ITSN1 lacks RNA- and DNA-binding motifs, it could be suggested that the effect of ITSN1 on the observed nucleus-specific processes is mediated by RNA-binding proteins including SAM68 or LARP6 and could be associated with pro- or anti-oncogenic signalling. The identification of multiple proline motifs-containing RBPs supports the suggestion that ITSN1/2 proteins might interact with other proteins involved in RNA processing although the functional consequence of possible interactions is still unknown. As a result, it can be suggested that the interaction between ITSN proteins and nuclear RBPs could serve as a link between signaling processes in the cytoplasm and RNA processing in the nucleus. However, further analysis is needed to confirm the predictions and find out their functional role.

\section{Conclusion}

The SH3 domains of ITSN1 and ITSN2 interacted with the nuclear RNA-binding proteins SAM68, WBP11 and LARP6 in vitro whereas, in 293 cells, ITSN1/2 scaffolds formed the protein complexes with SAM68 and LARP6. Moreover, human proteome contains a large number of other nuclear RBPs that have putative SH3 domain-interacting proline-rich regions which could potentially interact with ITSN1 and ITSN2. Overall, it could be suggested that ITSN-RBPs complexes could be involved in the regulation of mRNA processing although the molecular basis of the potential relationship requires further analysis.

\section{Acknowledgments}

The authors thank Dr. D. J. Elliott for GFPtagged SAM68, Dr. M. Bollen for GFP-tagged 
WBP11, Dr. L. M. Schwartz for GFP-tagged LARP6, and Dr. V. V. Filonenko for the kind gift of polyclonal anti-GFP antibodies.

\section{Funding}

This work was supported by the grant №0115U002947 "Mechanisms of invadopodia functioning and expression of their components in the breast cancer disease" as a part of the interdisciplinary project of NAS of Ukraine "The molecular and cellular biotechnology in medicine, industry and agriculture".

\section{REFERENCES}

1. Good MC, Zalatan JG, Lim WA. Scaffold proteins: hubs for controlling the flow of cellular information. Science. 2011;332(6030):680-6.

2. Tsyba L, Nikolaienko O, Dergai O, Dergai M, Novokhatska O, Skrypkina I, Rynditch A. Intersectin multidomain adaptor proteins: regulation of functional diversity. Gene. 2011;473(2):67-75.

3. Hussain NK, Jenna S, Glogauer M, Quinn CC, Wasiak S, Guipponi M, Antonarakis SE, Kay BK, Stossel TP, Lamarche-Vane N, McPherson PS. Endocytic protein intersectin-1 regulates actin assembly via Cdc42 and N-WASP. Nat Cell Biol. 2001; 3(10):927-32.

4. Herrero-Garcia E, O'Bryan JP. Intersectin scaffold proteins and their role in cell signaling and endocytosis. Biochim Biophys Acta Mol Cell Res. 2017;1864(1):23-30.

5. Wang JB, Wu WJ, Cerione RA. Cdc42 and Ras cooperate to mediate cellular transformation by intersectin-L. J Biol Chem. 2005;280(24):22883-91.

6. Gryaznova T, Kropyvko S, Burdyniuk M, Gubar O, Kryklyva V, Tsyba L, Rynditch A. Intersectin adaptor proteins are associated with actin-regulating protein WIP in invadopodia. Cell Signal. 2015;27(7):1499508.

7. Russo A, O'Bryan JP. Intersectin 1 is required for neuroblastoma tumorigenesis. Oncogene. 2012; 31(46):4828-34.
8. Harris J, Herrero-Garcia E, Russo A, KajdacsyBalla A, O'Bryan JP, Chiu B. Silencing Intersectin 1 Slows Orthotopic Neuroblastoma Growth in Mice. $J$ Pediatr Hematol Oncol. 2017;39(8):e413-e418.

9. Gu F, Zhang H, Qin F, Liu X, Li W, Fu L, Ying G, Li B, Zhang $M, M a Y$. Intersectin1-S, a multidomain adapter protein, is essential for malignant glioma proliferation. Glia. 2015;63(9):1595-605.

10. Ma Y, Wang B, Li W, Ying G, Fu L, Niu R, Gu F. Reduction of intersectin1-s induced apoptosis of human glioblastoma cells. Brain Res. 2010; 1351: 222-8.

11. Ma Y, Wang B, Li W, Liu X, Wang J, Ding T, Zhang J, Ying $G, F u L, G u F$. Intersectin1-s is involved in migration and invasion of human glioma cells. $J$ Neurosci Res. 2011;89(7):1079-90.

12. Jeganathan N, Predescu D, Zhang J, Sha F, Bardita C, Patel M, Wood S, Borgia JA, Balk RA, Predescu $S$. Rac1-mediated cytoskeleton rearrangements induced by intersectin-1s deficiency promotes lung cancer cell proliferation, migration and metastasis. Mol Cancer. 2016;15(1):59.

13. Specht K, Harbeck N, Smida J, Annecke K, Reich U, Naehrig J, Langer R, Mages J, Busch R, Kruse E, Klein-Hitpass L, Schmitt M, Kiechle M, Hoefler H. Expression profiling identifies genes that predict recurrence of breast cancer after adjuvant CMFbased chemotherapy. Breast Cancer Res Treat. 2009;118(1):45-56.

14. Beausoleil SA, Jedrychowski M, Schwartz D, Elias JE, Villén J, Li J, Cohn MA, Cantley LC, Gygi SP. Large-scale characterization of HeLa cell nuclear phosphoproteins. Proc Natl Acad Sci U S A. 2004; 101(33):12130-5.

15. Alvisi G, Paolini L, Contarini A, Zambarda C, Di Antonio V, Colosini A, Mercandelli N, Timmoneri $M$, Palù $G$, Caimi L, Ricotta D, Radeghieri A. Intersectin goes nuclear: secret life of an endocytic protein. Biochem J. 2018;475(8):1455-1472.

16. Wong KA, Wilson J, Russo A, Wang L, Okur MN, Wang X, Martin NP, Scappini E, Carnegie GK, $O$ 'Bryan JP. Intersectin (ITSN) family of scaffolds function as molecular hubs in protein interaction networks. PLoS One. 2012;7(4):e36023.

17. Thalappilly S, Suliman M, Gayet $O$, Soubeyran $P$, Hermant A, Lecine P, Iovanna JL, Dusetti NJ. Iden- 
tification of multi-SH3 domain-containing protein interactome in pancreatic cancer: a yeast two-hybrid approach. Proteomics. 2008;8(15):3071-81.

18. Asbach B, Ludwig C, Saksela K, Wagner R. Comprehensive analysis of interactions between the Src-associated protein in mitosis of $68 \mathrm{kDa}$ and the human Src-homology 3 proteome. PLoS One. 2012;7(6):e38540.

19. Nikolaienko O, Skrypkina I, Tsyba L, Fedyshyn Y, Morderer D, Buchman V, de la Luna S, Drobot L, Rynditch $A$. Intersectin 1 forms a complex with adaptor protein Ruk/CIN85 in vivo independently of epidermal growth factor stimulation. Cell Signal. 2009;21(5):753-9.

20. Novokhatska O, Dergai M, Tsyba L, Skrypkina I, Filonenko V, Moreau J, Rynditch A. Adaptor proteins intersectin 1 and 2 bind similar proline-rich ligands but are differentially recognized by $\mathrm{SH} 2$ domaincontaining proteins. PLoS One. 2013;8(7):e70546.

21. Venables JP, Dalgliesh C, Paronetto MP, Skitt L, Thornton JK, Saunders PT, Sette C, Jones KT, Elliott DJ. SIAH1 targets the alternative splicing factor T-STAR for degradation by the proteasome. Hum Mol Genet. 2004;13(14):1525-34.

22. Llorian M, Beullens $M$, Lesage B, Nicolaescu E, Beke L, Landuyt W, Ortiz JM, Bollen M. Nucleocytoplasmic shuttling of the splicing factor SIPP1. $J$ Biol Chem. 2005;280(46):38862-9.

23. Shao R, Scully SJ Jr, Yan W, Bentley B, Mueller J, Brown C, Bigelow C, Schwartz LM. The novel lupus antigen related protein acheron enhances the development of human breast cancer. Int $J$ Cancer. 2012;130(3):544-54.

24. Giudice G, Sánchez-Cabo F, Torroja C, Lara-Pez$z i E$. ATtRACT-a database of RNA-binding proteins and associated motifs. Database (Oxford). 2016;2016. pii: baw035.

25. Cook KB, Kazan H, Zuberi K, Morris Q, Hughes TR. RBPDB: a database of RNA-binding specificities. Nucleic Acids Res. 2011;39(Database issue):D301-8.

26. Huntley RP, Sawford T, Mutowo-Meullenet P, Shypitsyna A, Bonilla C, Martin MJ, O'Donovan C. The GOA database: gene Ontology annotation updates for 2015. Nucleic Acids Res. 2015;43(Database issue):D1057-63.
27. Teyra J, Huang H, Jain S, Guan X, Dong A, Liu Y, Tempel W, Min J, Tong Y, Kim PM, Bader GD, Sidhu SS. Comprehensive Analysis of the Human SH3 Domain Family Reveals a Wide Variety of Non-canonical Specificities. Structure. 2017;25(10): 1598-1610.e3.

28. Frisone P, Pradella D, Di Matteo A, Belloni E, Ghigna C, Paronetto MP. SAM68: Signal transduction and RNA metabolism in human cancer. BioMed Res Int. 2015; 2015: 528954.

29. Hong W, Resnick RJ, Rakowski C, Shalloway D, Taylor SJ, Blobel GA. Physical and functional interaction between the transcriptional cofactor CBP and the KH domain protein Sam68. Mol Cancer Res. 2002;1(1):48-55.

30. Taylor SJ, Resnick RJ, Shalloway D. Sam68 exerts separable effects on cell cycle progression and apoptosis. BMC Cell Biol. 2004;5:5.

31. Yang JP, Reddy TR, Truong KT, Suhasini M, WongStaal F. Functional interaction of Sam68 and heterogeneous nuclear ribonucleoprotein K. Oncogene. 2002;21(47):7187-94.

32. Rajan P, Gaughan L, Dalgliesh C, El-Sherif A, Robson CN, Leung HY, Elliott DJ. The RNA-binding and adaptor protein Sam68 modulates signaldependent splicing and transcriptional activity of the androgen receptor. J Pathol. 2008;215(1):67-77.

\section{Скафолдні білки ITSN1 та ITSN2 взаємодіють із ядерними РНК-зв'язуючими білками}

С. В. Паньківський, Н. В. Сенченко, П. Б. Бусько, А. В. Риндич

Мета. Виявити нових партнерів ITSN1 і ITSN2 3-поміж РНК-зв'язуючих білків (RBP), що беруть участь в регуляції процесингу мРНК. Методи. Взаємодії були проаналізовано з використанням GST pull-down assay та імунопреципітації, тоді як біоінформатичний аналіз було використано для ідентифікації інших RBP, які могли б взаємодіяти із білками ITSN1 та ITSN2. Результати. Було показано, що SH3 домени білків ITSN1 та ITSN2 взаємодіють з ядерними RBP SAM68, WBP11 і LARP6. Крім того, було виявлено, що ITSN1 та ITSN2 копреципітувались із SAM68 і LARP6 із лізатів клітин лінії 293. Біоінформатичний аналіз пока- 
зав, що існує більше 500 ядерних RBP, які містять кілька пролінових мотивів, що можуть взаємодіяти із SH3 доменами білків ITSN1/2. Висновки. SH3 домени білків ITSN1 і ITSN2 взаємодіють із ядерними RBP SAM68, LARP6 i WBP11 in vitro, утворюють комплекси із SAM68 і LARP6 в клітинах лінії 293 і потенційно можуть взаємодіяти з іншими ядерними RBP, що містять мотиви, які зв'язуються із $\mathrm{SH} 3$ доменами.

К л ю ч о в і с сл о в а: ITSN1, ITSN2, РНК-зв'язуючі білки.

\section{Скаффолдные белки ITSN1 и ITSN2 взаимодействуют с ядерными РНК- связывающими белками}

С. В. Паньковский, Н. В. Сенченко, П. Б. Бусько, А. В. Рындич

Цель. Найти новых партнеров ITSN1 и ITSN2 среди РНК-связывающих белков (RBP), участвующих в регуляции процессинга мРНК. Методы. Взаимодействия были проанализированы с использованием GST pulldown assay и иммунопреципитации, тогда как биоин- форматический анализ был проведен для идентификации других RBP, которые могли бы взаимодействовать с белками ITSN1 и ITSN2. Результаты. Было показано, что SH3 домены белков ITSN1 и ITSN2 взаимодействуют с ядерными RBP SAM68, WBP11 и LARP6. Кроме того, было обнаружено, что ITSN1 и ITSN2 копреципитировались с SAM68 и LARP6 из лизатов клеток линии 293. Биоинформатический анализ показал, что существует более 500 ядерных RBP, содержащие несколько пролиновых мотивов, которые могут взаимодействовать с SH3 доменами белков ITSN1/2 в ядре клетки. Выводы. SH3 домены белков ITSN1 и ITSN2 взаимодействуют с ядерными RBP SAM68, LARP6 и WBP11 in vitro, образуют комплексы c SAM68 и LARP6 в клетках линии 293 и потенциально могут взаимодействовать с другими ядерными RBP, содержащими мотивы, которые связываются с SH3 доменами.

К л юч е в ы е с л о в а: ITSN1, ITSN2, РНК-связываюмщие белки 